\title{
Tiludronate infusion in horses previously submitted to bone scintigraphy
}

\author{
Evaluación de la infusión de tiludronato en caballos \\ previamente sometidos a cintigrafía ósea
}

\author{
CA Dörner*, MC Rick, CE Judy
}

\begin{abstract}
This study was performed to evaluate the systemic short-term effects of tiludronate intravenous infusion on serum biochemical variables when administered as one single-dose in horses that undergo bone scintigraphy within 24 to 36 hours prior to treatment. Thirty-eight horses were enrolled in the study. Fifteen horses received a dose of technetium $(0.3 \mathrm{mCi} / \mathrm{kg}), \mathrm{MDP}(20 \mathrm{mg}$; medronate) and another fifteen horses received technetium ( $0.3 \mathrm{mCi} / \mathrm{kg}), \mathrm{MDP}(20 \mathrm{mg})$, and furosemide $(1 \mathrm{mg} / \mathrm{kg})$. Then, 24 to 36 hours after the bone scintigraphy, eight horses were selected and received tiludronate $(500 \mathrm{mg}$ in $5 \mathrm{~L}$ of $0.9 \% \mathrm{NaCl})$. Blood samples were collected 15 minutes prior, 24 and 48 hours after the treatment and a chemistry panel was assayed on the day of collection. Serum chemistry values were not significantly different between horses receiving tiludronate and those in both control groups. Additionally, one horse showed mild transient signs of colic recorded as pacing and stretching in the stall after 3 hours the injection of the tiludronic acid. The results suggest that tiludronate can be administered safely as one single dose in horses having undergone recent bone scintigraphy without additional complications or detrimental effect other than those previously described for the drug.

Key words: horse, bisphosphonates, tiludronate, bone scintigraphy.
\end{abstract}

RESUMEN. Este estudio se realizó para evaluar los efectos sistémicos a corto plazo de la infusión endovenosa de ácido tiludrónico en aquellos caballos que son sometidos previamente a cintigrafía ósea. 38 caballos participaron de este estudio. 15 ejemplares recibieron tecnecio $(0,3 \mathrm{mCi} / \mathrm{kg}), \mathrm{MDP}(20 \mathrm{mg})$ y 15 recibieron tecnecio $(0,3 \mathrm{mCi} / \mathrm{kg}), \mathrm{MDP}(20 \mathrm{mg})$ y furosemida $(1 \mathrm{mg} / \mathrm{kg})$. Posteriormente, 8 caballos fueron seleccionados para recibir tiludronato $(500 \mathrm{mg}$ en $5 \mathrm{~L}$ de $0,9 \% \mathrm{NaCl}$ ). Muestras sanguíneas fueron obtenidas 15 minutos antes, 24 horas y 48 horas después de cada tratamiento (cintigrafía y tiludronato), las que fueron evaluadas mediante un perfil bioquímico. Los valores sanguíneos entre los grupos control y el grupo de caballos que recibieron tiludronato no presentaron diferencias estadísticamente significativas. Adicionalmente, 3 horas después de la infusión con ácido tiludrónico, un caballo presentó signos leves de cólico, los que fueron registrados como ambular excesivo y movimientos de estiramiento en la pesebrera. Los resultados de este estudio sugieren que el ácido tiludrónico puede ser administrado en una sola dosis $(500 \mathrm{mg})$ en caballos previamente sometidos a cintigrafía ósea, en forma segura sin ninguna otra complicación o efecto detrimental que los ya descritos para esta droga.

Palabras claves: caballo, bifosfonatos, tiludronato, cintigrafía ósea.

\section{INTRODUCTION}

Bisphosphonates are known for their ability to reduce the osteoclastic activity and thus bone resorption. They have been widely used in human medicine for the treatment of osteoporosis (Shen et al 2011), Paget's disease (Harinck et al 1987), metastatic bone disease (Barni et al 2006), multiple myeloma (Kanis et al 2000) and hypercalcaemia of malignancy (Major et al 2001). Nowadays, the use of tiludronic acid in horses to treat orthopedic conditions with increased bone remodeling such as navicular syndrome (Denoix et al 2003) using the recommended dose of 0.1 $\mathrm{mg} / \mathrm{kg}$ bw per day for 10 days (EMEA 2001), or osteoarthritis of the thoracolumbar vertebral column (Coudry et al 2007) and bone spavin (Gough et al 2010) using a dosage of $1 \mathrm{mg} / \mathrm{kg}$ bw as a single-dose have been well-described and both dosage regimens of tiludronate seems to work equally well (Delguste et al 2008).

Accepted: 14.01.2016.

Alamo Pintado Equine Medical Center, Los Olivos, CA, USA.

*Corresponding author: CA Dörner; Avenida Larraguibel S/N, San Isidro, Quillota, Chile; cdorner@gmail.com
Tiludronate is a non-N-containing bisphosphonate licensed for use in the equine species (Tildren ${ }^{\circledR}$ ) and humans $\left(\operatorname{Skelid}^{\circledR}\right)$. Its primary pharmacological target is the osteoclast, and its effects are mostly mediated through the intra-cellular production of cytotoxic ATP analogs. After tiludronate is metabolized in the cell, the resulting compounds replace the terminal pyrophosphate moiety of ATP, forming a non-functional molecule that competes with adenosine triphosphate in the cellular energy metabolism inducing cell death (Rogers et al 2000, Roelofs et al 2006). On the other hand, the $\mathrm{N}$-containing bisphosphonates inhibit farnesyl diphosphate synthase, an enzyme of the mevalonate pathway, thereby preventing prenylation of small GTPase signaling proteins required for osteoclast function (Rogers et al 2000, Roelofs et al 2006).

The pharmacological properties of tiludronate in laboratory animals and in humans have been extensively described (EMEA 2001). Nonetheless, a commonly occurring situation in our hospital is the use of tiludronate in horses after they have undergone bone scintigraphy were another, radioisotope-labeled bisphosphonate (medronate) is used. The cumulative effect of bisphosphonates could be potentially negative and detrimental, as known side effect such as possible kidney compromise or occurrence 
of colic may be worsened. However, this has not been investigated before.

The objective of this study is to show the short-term effects in the serum chemistry values after the infusion of $500 \mathrm{mg}$ of tiludronate and evaluate its safety in horses when administered as a single-dose after bone scintigraphy.

\section{MATERIAL AND METHODS}

HORSES

Thirty-eight horses between 2- to 16-years were used for the study. All the horses included in the study were referred or presented to APEMC with history of lameness with a duration $>3$ weeks and were included in the trial according to the results of the lameness and imaging examination. Horses included in the tiludronate group fulfilled the following imaging criteria on the affected limb: a) radiographic findings on 3 projections of the navicular bone (lateromedial, dorsoproximal-palmarodistal $60^{\circ}$ oblique and palmaroproximal-palmarodistal oblique) with osteolytic lesions of the distal sesamoid bone, proximal or distal entheseophytes, periarticular osteophytes, sclerosis of either the flexor compact bone or the spongiosa b) scintigraphic findings: increased radiopharmaceutical uptake of the navicular bone. Moreover, they had a substantial improvement of lameness after distal palmar digital nerve block. Gender, breed or training status were not considered as a criterion for the trial. They were allocated into two groups: a control group $(n=30)$ and a treatment group in which tiludronate was administered $(n=8)$. The housing of animals was in $3 \times 4 \mathrm{~m}$ stalls. Water was supplied ad libitum and feeding consisted in alfalfa and timothy hay, distributed in two daily meals.

\section{TREATMENTS}

All the horses in the control group underwent bone scintigraphy ${ }^{1} .15$ horses were allocated to a control subgroup-a (BS) in which the horses received a dose of $20 \mathrm{mg}$ of MDP (medronate) labeled with technetium-99m ((0.3 $\mathrm{mCi} / \mathrm{kg}[0.14 \mathrm{mCi} / \mathrm{lb}], \mathrm{IV})$ ). The control subgroup-b (BSF; $\mathrm{n}=15)$ received technetium $-99 \mathrm{~m}((0.3 \mathrm{mCi} / \mathrm{kg}[0.14 \mathrm{mCi} /$ lb], IV)), $20 \mathrm{mg}$ of medronate and $1 \mathrm{mg} / \mathrm{kg}$ of furosemide ${ }^{2}$ (Dyson 2007) necessary for the full body and hind end bone scintigraphy. Each treatment was administered via a polyurethane catheter placed in the left jugular vein after aseptic preparation of the skin. At the time of imaging, horses were sedated with detomidine hydrochloride $(0.01$ to $0.03 \mathrm{mg} / \mathrm{kg}$ [0.005 to $0.014 \mathrm{mg} / \mathrm{lb}], \mathrm{IV})^{3}$ and butorphanol

\footnotetext{
Ultra Scan gamma camera, Enhanced Technologies, Hurst, TX.

Salix ${ }^{\circledR}$, Merck Animal Health, Summit, NJ.

Dormosedan ${ }^{\circledR}$, Orion Corporation, Espoo, Finland.
}

tartrate (0.01 to $0.02 \mathrm{mg} / \mathrm{kg}$ [0.005 to $0.009 \mathrm{mg} / \mathrm{lb}], \mathrm{IV})^{4}$. Subsequent to the procedure, the IV catheter was removed. The tiludronate group ( $\mathrm{T} ; \mathrm{n}=8$ ) was treated with $500 \mathrm{mg}$ tiludronate ${ }^{5}$ which was administered by slow intravenous infusion over 50 to 60 minutes in $5 \mathrm{~L}$ of saline solution $(0.9 \% \mathrm{NaCl})^{6}$. The horses in the $\mathrm{T}$ group were submitted to bone scintigraphy, without furosemide, 24-36 hours prior to the tiludronate injection. Each treatment was administered via a polyurethane catheter placed in the right jugular vein after aseptic preparation of the skin.

\section{BLOOD SAMPLES}

Blood samples were collected from the jugular vein via venipuncture 15 minutes prior to and 24 and 48 hours after tiludronate treatment in BD Vacutainer ${ }^{\circledR}$ lithium heparin tubes. A chemistry panel was assayed on the day of collection using the in-house Catalyst Dx® Chemistry Analyzer ${ }^{7}$. Total protein (TP), albumin (Alb), globulin (Glob) alkaline phosphatase(ALKP), gamma-glutamyl transpeptidase (GGT), glucose (Glu), creatinine (Creat), blood urea nitrogen (BUN), calcium $(\mathrm{Ca})$, phosphorus (Phos) and total bilirubin (Tbil) were measured.

\section{STATISTICAL ANALYSIS}

Statistical analyses were run on SPSS, version 19 for Windows (SPSS Inc, Chicago IL, USA). A linear mixed-designed ANOVA for repeated-measures was performed. Normal probability plots determined with Shapiro-Wilk test revealed that all data followed a normal distribution. Subsequently, means and standard deviations were used for the quantitative parameters. Treatment differences between protocols were adjusted for multiple comparisons with parametric Tukey procedure. On the other hand, overall difference between the means at the different time points within each group was determined with a GreenhouseGeisser correction and complemented with the pairwise comparisons using Bonferroni post-hoc test. Significance threshold was set at $\mathrm{P}<0.05$.

\section{RESULTS AND DISCUSSION}

This study was performed to evaluate the systemic short-term effects of tiludronate intravenous infusion administered as a one single-dose in horses that underwenr bone scintigraphy within 24 to 36 hours prior to treatment, a common situation occurring in our hospital. It was possible to observe a large number of horses showing signs

4 Dolorex®, Merck Animal Health, Summit, NJ.

5 Tildren®, CEVA Sante Animale, Libourne, France.

$6 \quad 0.9 \%$ Sodium Chloride, Abbott Laboratories, North Chicago, IL.

7 IDEXX Laboratories Inc., Westbrook, ME. 
of colic and presenting increased blood nitrogen (BUN), creatinine, calcium above the normal range and decreased phosphorus under the normal range (unpublished data), clearly indicating renal damage that could result in renal failure, when treated with tiludronate as a single dose (1 $\mathrm{mg} / \mathrm{kg} \mathrm{bw}$ ) in 1 liter of lactated ringer's solution.

Thirty-eight horses (mean age: $9 \pm 3.97$ years, $55.3 \%$ geldings, $42.1 \%$ mares and $2.6 \%$ stallions) were enrolled in this study based on a history of lameness with a duration $>3$ weeks. The eight horses enrolled in the treatment group were selected based on the results of lameness and imaging techniques (radiographs of the lower digit and bone scintigraphy).

No significant differences were observed in the systemic, liver and kidney blood parameters between the control groups and the treatment group $(\mathrm{P}<0.05)$ (tables 1 and 2 , figure 1). Additionally, no significant differences were seen within the groups at the different times with one exception: BUN increased in group BSF from pre-treatment values and 24 hours post treatment $(\mathrm{P}<0.05)$. Nonetheless, all BUN values remained within normal reference range described for the specie.
The primary target of tiludronic acid has traditionally been the bone tissue. Nowadays, intravenous administration of tiludronic acid is frequently used for the treatment of navicular disease or distal tarsal joint osteoarthritis and it has been demonstrated to be a successful therapy for these diseases in some horses. On the other hand, studies have shown that tiludronate also exerts some direct effects on cartilage and chondrocytes (Duesterdieck-Zellmer et al 2012, Duesterdieck-Zellmer et al 2014). Detrimental effects on cartilage and chondrocytes have been observed as the result of high synovial fluid tiludronate concentration (Duesterdieck-Zellmer et al 2012, Duesterdieck-Zellmer et al 2014) hence extra-label administration of tiludronate such as via regional limb perfusion or intraarticular injection may be harmful dependent on the dose used. Thus, a correct dose and route of administration are very important when the best possible outcome is wanted.

Nuclear scintigraphy is a safe and nontoxic imaging modality frequently used in horses. The most common radiopharmaceutical used for equine bone scintigraphy is $99 \mathrm{~m}$ TC-MDP (methylene diphosphonate or medronate) which indicates the turnover of bone and blood flow to

Table 1. Mean \pm SD values for blood parameter associated with systemic and liver function measured 15 minutes prior treatment, 24 hours, and 48 hours after treatment.( ALB, Albumin; ALPK, Alkaline phosphatase; GGT, Gamma-glutamyltransferase; GLOB, Globulins; GLU, Glucose; TBI,: Total Bilirubin; TP, Total Proteins).

Valor medio \pm DE de los parámetros sanguíneos asociados con función sistémica y hepática medidos 15 minutos pretratamiento, 24 horas y 48 horas postratamiento (ALB, Albúmina; ALKP, Fosfatasa alcalina; GGT, Gammaglutamil transferasa; GLOB, Globulinas; GLU, Glucosa; TBIL, Bilirrubina total; TP: Proteínas totales).

\begin{tabular}{|c|c|c|c|c|c|}
\hline Variable & Groups & Pre Treatment & Post Treatment $-24 \mathrm{hr}$ & Post Treatment - $48 \mathrm{hr}$ & Reference Interval $(*)$ \\
\hline & BS & $3.047 \pm 0.223$ & $3.007 \pm 0.225$ & $3.000 \pm 0.180$ & \\
\hline \multirow[t]{3}{*}{ ALB } & BSF & $3.040 \pm 0.232$ & $3.087 \pm 0.188$ & $3.070 \pm 0.167$ & $1.9-3.2 \mathrm{~g} / \mathrm{dL}$ \\
\hline & $\mathrm{TNaCl}$ & $2.871 \pm 0.149$ & $3.014 \pm 0.212$ & $2.957 \pm 0.127$ & \\
\hline & BS & $129.9 \pm 34.01$ & $131.3 \pm 27.46$ & $125.9 \pm 44.38$ & \\
\hline \multirow[t]{3}{*}{ ALKP } & BSF & $126.4 \pm 28.99$ & $129.7 \pm 34.81$ & $124.6 \pm 36.62$ & $10-326 \mathrm{U} / \mathrm{L}$ \\
\hline & $\mathrm{TNaCl}$ & $130.7 \pm 20.33$ & $148.6 \pm 34.65$ & $133.1 \pm 19.13$ & \\
\hline & BS & $19.47 \pm 4.502$ & $20.07 \pm 4.317$ & $20.47 \pm 4.882$ & \\
\hline \multirow[t]{3}{*}{ GGT } & BSF & $23.07 \pm 9.192$ & $21.40 \pm 10.08$ & $22.40 \pm 11.14$ & $0-87 \mathrm{U} / \mathrm{L}$ \\
\hline & $\mathrm{TNaCl}$ & $20.43 \pm 7.091$ & $22.43 \pm 4.117$ & $19.71 \pm 2.360$ & \\
\hline & BS & $3.560 \pm 0.356$ & $3.530 \pm 0.269$ & $3.480 \pm 0.270$ & \\
\hline \multirow[t]{3}{*}{ GLOB } & BSF & $3.467 \pm 0.266$ & $3.473 \pm 0.293$ & $3.440 \pm 0.269$ & $2.4-4.7 \mathrm{~g} / \mathrm{dL}$ \\
\hline & $\mathrm{TNaCl}$ & $3.486 \pm 0.241$ & $3.543 \pm 0.287$ & $3.543 \pm 0.282$ & \\
\hline & BS & $114.5 \pm 19.97$ & $109.0 \pm 10.47$ & $104.5 \pm 8.417$ & \\
\hline \multirow[t]{3}{*}{ GLU } & BSF & $108.3 \pm 11.12$ & $102.3 \pm 11.67$ & $103.4 \pm 10.03$ & $64-150 \mathrm{mg} / \mathrm{dL}$ \\
\hline & $\mathrm{TNaCl}$ & $104.4 \pm 5.318$ & $108.0 \pm 14.26$ & $101.6 \pm 4.860$ & \\
\hline & BS & $1.467 \pm 0.362$ & $1.547 \pm 0.358$ & $1.390 \pm 0.376$ & \\
\hline \multirow[t]{3}{*}{ TBIL } & BSF & $1.180 \pm 0.416$ & $1.320 \pm 0.443$ & $1.207 \pm 0.371$ & $0.0-3.5 \mathrm{mg} / \mathrm{dL}$ \\
\hline & $\mathrm{TNaCl}$ & $1.514 \pm 0.505$ & $1.543 \pm 0.535$ & $1.400 \pm 0.500$ & \\
\hline & BS & $6.620 \pm 0.500$ & $6.573 \pm 0.403$ & $6.503 \pm 0.363$ & \\
\hline \multirow[t]{2}{*}{ TP } & BSF & $6.493 \pm 0.371$ & $6.533 \pm 0.352$ & $6.490 \pm 0.292$ & $5.6-7.9 \mathrm{~g} / \mathrm{dL}$ \\
\hline & $\mathrm{TNaCl}$ & $6.357 \pm 0.299$ & $6.557 \pm 0.461$ & $6.500 \pm 0.346$ & \\
\hline
\end{tabular}

*Idexx laboratories 
Table 2. Mean \pm SD values for blood parameter associated with kidney function measured 15 minutes prior treatment, 24 hours, and 48 hours after treatment. (BUN, Blood urea nitrogen; CREAT, Creatinine; Ca, Calcium; PHOS, Phosphorus; B/C, blood urea nitrogen/ creatinine index).

Valor medio \pm DE de los parámetros sanguíneos asociados con función renal medidos 15 minutos pre tratamiento, 24 horas y 48 horas post tratamiento. (BUN, nitrógeno ureico sanguíneo; CREAT, Creatinina; $\mathrm{Ca}$, Calcio; PHOS, Fósforo; B/C, relación nitrógeno ureico sanguíneo/creatinina).

\begin{tabular}{llcccc}
\hline Variable & \multicolumn{1}{c}{ Groups } & Pre Treatment & Post Treatment $-24 \mathrm{hr}$ & Post Treatment $-48 \mathrm{hr}$ & Reference Interval $(*)$ \\
\hline \multirow{3}{*}{ BUN } & BS & $16.00 \pm 4.123$ & $17.20 \pm 4.427$ & $16.40 \pm 3.855$ & \\
& BSF & $15.13 \pm 2.997^{\mathrm{a}}$ & $17.60 \pm 3.202^{\mathrm{a}}$ & $16.83 \pm 3.462$ & $10-25 \mathrm{mg} / \mathrm{dL}$ \\
& $\mathrm{TNaCl}$ & $13.13 \pm 3.270$ & $12.88 \pm 4.580$ & $13.69 \pm 4.877$ & \\
CREAT & $\mathrm{BS}$ & $1.267 \pm 0.226$ & $1.287 \pm 0.275$ & $1.267 \pm 0.286$ & \\
& $\mathrm{BSF}$ & $1.227 \pm 0.237$ & $1.260 \pm 0.244$ & $1.260 \pm 0.203$ & $0.8-2.2 \mathrm{mg} / \mathrm{dL}$ \\
& $\mathrm{TNaCl}$ & $1.200 \pm 0.193$ & $1.323 \pm 0.259$ & $1.294 \pm 0.170$ & \\
$\mathrm{Ca}$ & $\mathrm{BS}$ & $12.29 \pm 0.519$ & $11.93 \pm 0.636$ & $11.96 \pm 0.746$ & \\
& $\mathrm{BSF}$ & $12.07 \pm 0.612$ & $12.01 \pm 0.654$ & $12.07 \pm 0.499$ & $10.4-12.9 \mathrm{mg} / \mathrm{dL}$ \\
& $\mathrm{TNaCl}$ & $11.74 \pm 0.743$ & $11.90 \pm 0.748$ & $12.06 \pm 0.556$ & \\
$\mathrm{PHOS}$ & $\mathrm{BS}$ & $3.573 \pm 0.521$ & $4.027 \pm 0.792$ & $3.887 \pm 0.979$ & \\
& $\mathrm{BSF}$ & $3.327 \pm 0.692$ & $3.380 \pm 0.728$ & $3.273 \pm 0.844$ & $1.8-5.6 \mathrm{mg} / \mathrm{dL}$ \\
& $\mathrm{TNaCl}$ & $3.414 \pm 0.474$ & $3.386 \pm 0.662$ & $3.429 \pm 0.415$ & \\
$\mathrm{~B} / \mathrm{C}$ & $\mathrm{BS}$ & $12.93 \pm 3.634$ & $13.67 \pm 3.395$ & $13.47 \pm 3.833$ & \\
& $\mathrm{BSF}$ & $12.80 \pm 3.610$ & $14.27 \pm 3.390$ & $13.47 \pm 3.159$ & $10-20$ \\
& $\mathrm{TNaCl}$ & $11.13 \pm 2.850$ & $10.00 \pm 3.423$ & $11.00 \pm 4.106$ & \\
\hline
\end{tabular}

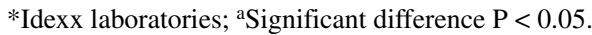

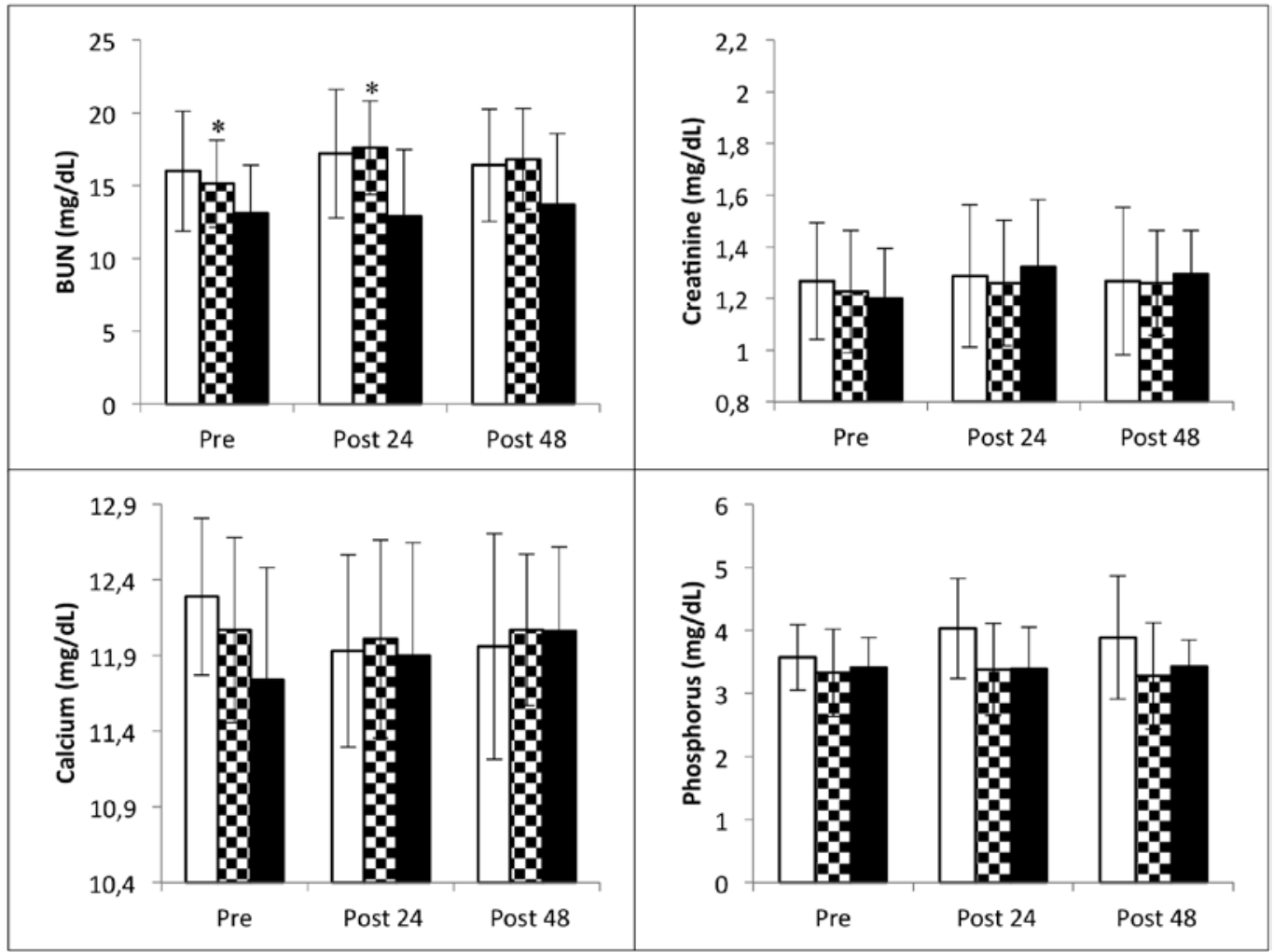

Figure 1. Mean \pm SD values for blood parameter associated with kidney function measured 15 minutes prior treatment, 24 hours, and 48 hours after treatment with technetium + MDP (BS = open bars), technetium + MDP + furosemide (BSF = dotted bars), and tiludronate $(\mathrm{T}=$ solid bars $)$ * Within a time point, values differs significantly $(\mathrm{P}<0.05)$.

Valor medio \pm DE para los parámetros sanguíneos asociados con la función renal medido 15 minutos pretratamiento, 24 horas y 48 horas postratamiento con tecnesio + MDP (BS = barras blancas), tecnesio + MDP + furosemida (BSF = barras punteadas) y tiludronato $(\mathrm{T}=$ barras negras). $*$ Entre dos puntos de tiempo, los valores son estadísticamente significativos $(\mathrm{P}<0,05)$. 
the bone (Driver 2003). Furosemide was used in one of the group to empty the bladder during the scan in order to minimise misinterpreting images of the pelvic region, coxofemoral and sometimes stifle joints due to radioactive urine (radiopharmaceutical are excreted principally in the urine). Results obtained from the control groups (BS and BSF) were normal as expected with no statistically significant difference between both control groups.

Intravenous administration of $500 \mathrm{mg}$ tiludronate in horses previously submitted to bone scintigraphy did not alter the blood values assessed and no significant differences were observed between groups. Similar findings were reported by Varela et al (2001), however, in that study a slight transient hypocalcaemia was seen at 30 minutes post-injection using a single dose of $1 \mathrm{mg} / \mathrm{kg}$ in 1 liter of $0.9 \%$ sodium chloride over 30 minutes. While kidney and hepatic parameters were normal in all horses 24 hours after tiludronate treatment, it is possible that parameters were elevated earlier after tiludronate infusion. Nonetheless, in the research mentioned above, the horses were not allowed to have any medication likely to affect bone metabolism 6 weeks prior tiludronate infusion, a situation quiet different from this study were the horses receiving tiludronate underwent bone scintigraphy 24 to 36 hours prior to the treatment with tiludronate. Additionally, in this study one horse showed mild transient signs of colic recorded as pacing and stretching in the stall 3 hours after the injection of the tiludronic acid, without abnormalities in the serum chemistry values, which resolved without further complications after intravenous injection of flunixin meglumine $(1 \mathrm{mg} / \mathrm{kg} \mathrm{bw})^{8}$. Flunixin meglumine is a commonly used drug in horses receiving tiludronate to treat the signs of colic presented in some horses either as preventive drug or as a medication when the signs are established. This non-steroidal anti-inflammatory drug is potentially nephrotoxic, therefore it could influence the occurrence of renal failure after tiludronate administration when used at the same time.

The objective of this study was not to evaluate the efficacy of the drug to modulate bone remodeling using this dosage regimen, however, it has been reported that CTX-1 suppression (a marker for bone break-down) was similar when tiludronate was administered to adult, healthy horses at a dose of $0.1 \mathrm{mg} / \mathrm{kg}$ body weight daily for 10 consecutive days compared to a single dose of $1.0 \mathrm{mg} / \mathrm{kg}$ body weight (Delguste et al 2008). Furthermore, given the information available there is no scientific reason that sustains a decreased efficacy of tiludronate when administered within 24 to 36 hours after a bone scintigraphy procedure.

The results of the present study complement information already available and suggest that tiludronic acid can be safely administered as one single dose $(1 \mathrm{mg} / \mathrm{kg}$ bw in

$8 \quad$ Prevail $^{\mathrm{TM}}$, Vetone, Boise, ID.
$5 \mathrm{~L}$ of $0.9 \% \mathrm{NaCl}$ ) in horses with normal serum chemistry values having undergone recent bone scintigraphy without complication or detrimental effects other than those already described for the drug which are generally transient and resolve with or without therapy. This situation may be different in horses that already have renal compromise prior to tiludronate administration. Finally, the impact of bone scintigraphy on the efficacy of the drug to modulate bone remodeling was not the focus of this study therefore its efficacy using this treatment scheme needs further investigation.

\section{ACKNOWLEDGEMENTS}

The authors would like to acknowledge Dr. D. Herthel for the financial support given for this study.

\section{REFERENCES}

Barni A, M Mandalà, M Cazzaniga, M Cabiddu, M Cremonesi. 2006. Bisphosphonates and metastatic bone disease. Ann Oncol 17, ii91-ii92.

Coudry V, D Thibaud, B Riccio, F Audigie, D Didierlaurent, JM Denoix. 2007. Efficacy of tiludronate in the treatment of horses with signs of pain associated with osteoarthritic lesions of the thora- columbar vertebral column. Am J Vet Res 68, 329-337.

Delguste C, H Amory, J Guyonnet, D Thibaud, P Garnero, J Detilleux, OM Lepage, M Doucet. 2008. Comparative pharmacokinetics of two intravenous administration regimens of tiludronate in healthy adult horses and effects on the bone resortion marker CTX-1. J Vet Pharmacol Therap 31, 108-116.

Denoix JM, D Thibaud, B Riccio. 2003. Tiludronate as a new therapeutic agent in the treatment of na-vicular disease: A double-blind placebocontrolled clinical trial. Equine Vet J 35, 407-413.

Driver A. 2003. Basic principles of equine scintigraphy In: Dyson SJ, Pilsworth RC, Twardock AR, Martinelli MJ (eds). Equine scintigraphy. $1^{\text {st }}$ ed. Equine Veterinary Journal Ltd., Newmarket, UK, Pp 15-22.

Duesterdieck-Zellmer KF, N Driscoll, JF Ott. 2012. Concentrationdependent effects of tiludronate on equine articular cartilage explants incubated with and without interleukin- $1^{\circledR}$. Am J Vet Res $73,1530-1539$.

Duesterdieck-Zellmer KF, L Moneta, JF Ott, M Larson, E Gorman, B Hunter, C Löhr, M Payton, J Morré, C Maier. 2014. Effects of low and high dose intraarticular tiludronate on synovial fluid and clinical variables in healthy horses-a preliminary investigation. PeerJ 2, e534.

Dyson S. 2003. Patient preparation In: Dyson SJ, Pilsworth RC, Twardock AR, Martinelli MJ (eds). Equine scintigraphy. $1^{\text {st }}$ ed. Equine Veterinary Journal Ltd, Newmarket, UK, Pp 15-22.

EMEA, European Agency fot the Evaluation of Medicinal Products. 2001. Tiludronic acid, disodium salt: summary report-committee for veterinary medicinal products. Reference Number: EMEA/ MRL/774/01-FINAL.

Gough MR, D Thibaud, RKW Smith. 2010. Tiludronate infusion in the treatment of bone spavin: A double blind placebo-controlled trial. Equine Vet J 42, 381-387.

Harinck H, SE Papapoulos, HJ Blanksma, AJ Moolenaar, P Vermeij, OLM Bijvoet. 1987. Paget's disease of bone: early and late responses to three different modes of treatment with aminohy- droxypropylidene bisphosphonate (APD). Br Med J 295, 1301-1305.

Kanis JA, EV McCloskey. 2000. Bisphosphonates in multiple myeloma. Cancer 88, 3022-3032.

Major P, A Lortholary, J Hon, E Abdi, G Mills, HD Menssen, F Yunus, R Bell, J Body, E Quebe-Fehling, J Seaman. 2001. Zoledronic acid is superior to pamidronate in the treatment of hypercal-caemia of 
malignancy: a pooled analysis of two randomized, controlled clinical trials. J Clin Oncol 19, 558-567.

Roelofs AJ, K Thompson, S Gordon, MJ Rogers. 2006. Molecular mechanisms of action of bisphos-phonates: Current status. Clin Cancer Res 12, 6222s-6230s.

Rogers MJ, S Gordon, HL Benford, FP Coxon, SP Luckman, J Mönkkönen, JC Frith. 2000. Cellular and molecular mechanisms of action of bisphosphonates. Cancer Supplement 88, 2961-2978.
Shen L, X Xie, Y Su, C Luo, C Zhang, B Zeng. 2011. Parathyroid hormone versus bisphosphonate treatment on bone mineral density in osteoporosis therapy: A meta-analysis of randomized controlled trials. Plos ONE 6, e26267.

Varela A, OM Lepage, M Doucet, M Marcoux, P Garnero. 2001. Tiludronate in horses: tolerance and short-term effect on bone metabolism. J Bone Miner Res 16, S407. 